JOURNAL OF SECURITY AND SUSTAINABILITY ISSUES ISSN 2029-7017 print/ISSN 2029-7025 online 2020 March Volume 9 Number 3 https://doi.org/10.9770/jssi.2020.9.3(9)

Scopus

\title{
THE DEFENSE-INDUSTRIAL COMPLEX AS THE BASIS OF THE NATIONAL SECURITY OF THE STATE
}

\author{
Dmytro Zhuravlov', Viktoriia Anishchuk ${ }^{2}$, Denys Chyzhov ${ }^{3}$, Volodymyir Pashynskyi ${ }^{4}$, Mykola Zaitsev $^{5}$ \\ ${ }^{1 *}$ Institute of Law and Postgraduate Education of the Ministry of Justice of Ukraine, \\ Sychovych Streltsivtsiv St., 73, Kyiv, 04053, Ukraine \\ ${ }^{2}$ Lutsk National Technical University, Lvivska street, 75, Lutsk, 43000, Ukraine \\ ${ }^{3}$ Military Institute of Taras Shevchenko National University of Kyiv, 81 Mikhail Lomonosov Street, Kyiv, 03680, Ukraine \\ ${ }^{4}$ National Defence University of Ukraine named after Ivan Cherniakhovskyi, Aeroflot Avenue, 30, Kyiv, 03186, Ukraine \\ ${ }^{5}$ Central Research Institute of the Armed Forces of Ukraine, 28b Povitroflotsky Ave., Kyiv, 03049, Ukraine
}

E-mail: ${ }^{*}$ koaduep@gmail.com (Corresponding author)

Received 15 March 2019; accepted 10 January 2020; published 30 March 2020

\begin{abstract}
The article examins the concept of the defense-industrial complex as the basis of the national security of the state, peculiarities of its structure and functioning in different countries of the world, as well as issues related the current state and reforms in Ukraine. In particular, the essence of the concept of defense-industrial complex is determined by researching the scientific points of view of both foreign and Ukrainian scientists. Peculiarities of the structure and functioning of the defense-industrial complex in countries like the USA, France, Italy, Great Britain, Sweden, China, India and Germany were studied. It was shown which state organs in Ukraine are responsible for production and supply (sales) of weapons and military equipment. The legal status of the State Concern "Ukroboronprom" as an important component of the defense-industrial complex of Ukraine has been determined. Special attention is paid to the peculiarities of the strategy of development of the defense-industrial complex of Ukraine for the period till 2028, its main purpose and priority directions are highlighted. Key strategic goals and key strategic initiatives in the State Concern "Ukroboronprom" reform strategy are highlighted, with the aim of achieving close international cooperation in the framework of innovative tendencies and improvement of the legal framework by bringing the legislation norms to the world standards. Problematic issues in the defense industry of Ukraine that need to be addressed in order to improve the efficiency and consistency of this sector of economy were identified.
\end{abstract}

Keywords: defense-industrial complex; military defense complex; national security of the state; Ukroboronprom; Ukraine

Reference to this paper should be made as follows: Zhuravlov, D., Anishchuk, V., Chyzhov, D., Pashynskyi, V., Zaitsev, M., 2020. The defense-industrial complex as the basis of the national security of the state. Journal of Security and Sustainability Issues, 9(3), 829-842. https://doi.org/10.9770/jssi.2020.9.3(9)

JEL Classifications: F35, F42

\section{Introduction}

As of today, in the developed countries, the defense-industrial complex is considered as an important component of the country's defense and national security strategy. As one of the sectors of the national economy, the purpose of the defense-industrial complex involves development and production of defense products. Considering the fact that the defense-industrial complex is the foundation of the national security of the state, the high level of its development requires constant upgrading of production facilities, which is one of the priorities of the national security policy in many countries.

The speed of scientific and technological progress and the growing needs of socio-economic development of the country necessitate the increase of the level of competitiveness of economic entities in any sphere of 
economy. The success and stability of functioning of domestic enterprises is explained by the need to identify and anticipate effective actions to adapt to the external economic environment and competitive advantages. Increasing the competitiveness of the enterprises of the defense-industrial complex is a necessary component of ensuring the national security of the country. In addition, concentration of significant intellectual potential and production resources in the defense-industrial complex, as well as support of high export potential are aimed at ensuring inflow of foreign currency to the state budget.

Transition of the enterprises of the defense-industrial complex to the market environment requires technological shifts and modernization of the industry in accordance with the world standards. Qualitative changes in the defense-industrial complex are aimed at preserving the efficiency of functioning and solving set tasks, taking into account national security interests of the country. Given the current integration processes of Ukraine's accession to the European Union, in order to enhance the country's defense and national security, it is important to carry out such foreign and defense policy that enables development of cooperation in the context of the European Union's security and defense policy and, consequently, maintenance of the international security.

\section{Literature Survey}

Exploring the essence of the concept of defense-industrial complex, it is important to note that in the scientific literature foreign scientists use the term «military-industrial complex».

So, Nzeribe \& Imam (2018) define the military-industrial complex (MIC) as an informal alliance between a nation's military and the defense industry that supplies it seen together as a vested interest which influences public policy. The authors emphasize that the driving factor behind this relationship between the government and defense-minded corporations is that both sides benefit: (1) one side from obtaining war weapons; (2) the other from being payed to supply them (Durmanov et. al., 2019).

In turn, Byrne (2017) notes that the military-industrial complex refers to a self-sustaining politico-economic system that supports profitability in military supply, in fact in many countries, but primarily in the United States. It consists of competing and / or cooperating organizations, the maintenance of which as a whole is financially beneficial to all interested sides. At the same time, it should be noted that the current state of financing of the defense-industrial complex of Ukraine does not show its self-sufficiency, whereby the corruption at the highest levels of government is a significant factor that caused such situation. In general, as noted by Kulish A., Andriichenko N., Reznik O., political corruption is a negative phenomenon that is known not only to Ukraine but also to a number of other countries in the world, which impedes democratic and economic development of the state (Kulish A., Andriichenko N., Reznik O., 2018).

Exploring the historical origins of the consept of the military-industrial complex, Smart (2016) points out that this was to describe the configuration of interests that led business corporations and the military to increasingly close relationships.

In his research, Qureshi (2018) explains the concept of a military-industrial complex as phenomena, processes, structure, and a set of agreements that take place between the military and industry of a certain country. To design MIC as an objective reality, it is defined as a structural network between its armed forces and the political and economic complex, in which there is a regulated but relatively intense flow of technologies, finance, services and products.

In Ukraine, the concept under study is called the defense-industrial complex. The authors' team of Avanesova et al. (2018) define the defense-industrial complex as a generator of advanced scientific, technical, technological achievements and developments, which allow to create not only advanced equipment of high-level of complexity, but also high-tech products of conversion purpose (Sitdikova \& Starodumova, 2019). 
Potomkina (2018) defines the defense-industrial complex as a coherent system comprising enterprises, institutions, organizations that are regarded as objects on the one hand, because they are engaged in the development and production of weapons, ammunition, military equipment, special components for them; and on the other hand, as economic entities subordinated to entities of organizational and economic authority in accordance with the powers conferred upon them by law, which participate in the placement, execution of the state defense order, have regulating and controlling functions over the activity of sub economic entities in the field of defenseindustrial complex, for which they exercise normative, managerial, administrative, control functions.

According to Solopenko (2016), the defense-industrial complex is one of the most important sectors of the economy of the country that needs investment, since this complex is a means that ensures the defense capability of the country, its inviolability and protects the sovereignty of the country. The scientist also emphasizes that previously the defense-industrial complexes in many countries of the world (Ukraine is no exception) focused on ensuring the defense capabilities of the national armed forces. But today, the latest trends in the development of the world defense industry have been marked by a shift from a purely self-oriented approach to the development of a global market for weapons and military equipment as a high-yielding source (Balanovska, et. al., 2019).

It is also important to note that the concept of "defense-industrial complex" in Ukraine has been studied not only at the doctrinal level, but also has legislative support. According to paragraph 13 of Part 1 of Art. 1 of the Law of Ukraine "On national security of Ukraine" the defense-industrial complex of Ukraine for the legislator means the totality of state organs, enterprises, institutions and organizations of industry and science, which develop, produce, modernize and utilize military products, provide services in the interests of defense for equipment and provision of security and defense forces, as well as supplying military and dual-use items, providing military services during implementation of military-technical cooperation of Ukraine with other countries (Law of Ukraine On national security of Ukraine, 2018).

\section{Methods}

The research of the concept of defense-industrial complex as a basis of national security of the state, peculiarities of its structure and functioning in different countries of the world, as well as issues of the current state and reforms in Ukraine was carried out using dialectical, formal-legal and system-structural methods.

So, to establish the essence of the concept of the defense-industrial complex by researching the scientific points of view of both foreign and Ukrainian scientists, the dialectical method was applied.

By means of the formal-legal method, the content of the norms of some of the current normative-legal acts of Ukraine was explored, which regulate: (1) the powers of the responsible organs in matters of production and transfer (supply, sale) of arms and military equipment; (2) the legal status of the State Concern "Ukroboronprom" as an important component of the defense-industrial complex of Ukraine, as well as peculiarities of its reformation; (3) strategy for development of the defense-industrial complex of Ukraine for the period till 2028, etc.

Using the system-structural method allowed to identify key strategic goals and key strategic initiatives in the reform Strategy of the State Concern "Ukroboronprom", aimed at achieving close international cooperation within the framework of innovative tendencies and improving the legal framework by bringing legislation norms in line with the world standards (Korauš et.al., 2019).

\section{Results}

The defense-industrial complex is an important part of the modern research and production sectors of the world economy. The largest defense industry companies in the world are represented by multidisciplinary multilevel structures, which include specialized units whose activities are aimed at development and production of hightech military and civilian products (Khmara, 2016). 
Thus, in the United States, functioning of the defense-industrial complex is based on two main strategic directions: (1) restructuring (merger and consolidation) of enterprises; (2) diversification of production (entry into non-defense markets). It is important to note that in the process of merger, the state does not remain on the sidelines, but rather controls, because most of such agreements are regulated by antitrust law and can have a negative impact on the competitiveness of US industry on the world markets. Thus, merger of companies in the defense-industrial complex is possible, but the United States Department of Defence is monitoring that the potential for production of all types of weapons and military equipment should be kept up. To this end, direct and indirect subsidies are provided. The Department of Defense allows businesses to include restructuring costs (redundancy payments, unemployment benefits, etc.) in defense contracts. At the same time, in return for such subsidies, defense companies are expected to return savings to the state through reduced prices for their products in the future (Usachenko, 2019).

The Defense Advanced Research Projects Agency (DARPA) was created in the United States in 1958 as an agency of the US Department of Defense. DARPA's priority is to ensure american military technology excellence over other countries in the world. DARPA annual budget exceeds USD 3 billions and it is structured into 7 major divisions: (1) Adaptive Execution Office (AEO); (2) Defense Sciences Office (DSO); (3) Information Innovation Office (I20); (4) Microsystems Technology Office (ITO); (5) Strategic Technology Office; (6) Tactical Technology Office (TTO); (7) Biological Technologies Office (BTO) (Defense advanced research projects agency (DARPA).

In France, to provide the Armed Forces with military equipment and weapons, in the structure of the Ministry of Defense of France there is the Directorate General of Arms (Direction générale de l'armement (DGA). As a contracting authority for armament programs, the DGA is responsible for development, acquisition, and evaluation of systems that provide the armed forces. According to DGA official website, it is currently carrying out 80 armament programs. As a major partner in the international development of French companies, DGA exports arms that is $1 / 3$ of the activity of French companies in the sector over the past ten years. In the defense sector DGA: (1) reviews armament systems to ensure their overall consistency; (2) investigates the ability to control risks to manage complex projects; (3) develops unique ways of evaluating and testing (4) pursues an industrial and technological policy with a European dimension; (5) actively contributes to the export of weapons (Direction générale de l'armement (DGA), The official website).

The major French companies that have become world leaders in the defense industry are Thales and Safran. In the field of defense and security, the armed forces, governments and global organizations task Thales to assist them in achieving and maintaining security, tactical superiority and strategic independence against any type of threat. In an increasingly unpredictable world, governments rely on the Thales experience to protect their citizens and make the world safer, from developing smart sensors and connecting soldiers in the digital battlefield to delivering solutions that protect countries, cities and critical infrastructure. In the defense industry, Thales has a strong reputation for high-performance decision-making and strong investment in key scientific fields. More than 50 countries rely on Thales solutions to protect their populations, including the United States, Canada, Latin America, Brazil, European countries (France, Germany, the United Kingdom, Italy, Spain, the Netherlands, Poland, etc.), Asia (India, China, Thailand, Japan, Malaysia, etc.), as well as Africa, Egypt, Morocco, the United Arab Emirates, etc. (Thales, The official website).

Another international high-tech defense group is Safran, a French company listed on the NYSE Euronext Paris. It is part of the French Stock Market Index, CAC 40 and the European Market Index, Euro Stoxx 50. The Executive Board that represents different companies of the Group fulfils strategic goals set by the Board of Directors. This management principle guarantees balance of power and ensures rapid response of Safran to the changing demands of the economic, financial and competitive environment. Safran offers innovative systems and equipment for armies, navies and air forces around the world. As a longtime partner of governments and their armed forces, Safran designs, manufactures and markets systems and equipment tailored to each country's specific defense needs. Operating in today's digital combat environment, Safran equipment guarantees efficiency and precision required for all weapons systems. Safran offers innovative solutions for navigation, optics, 
tactical information and stabilization on fighter jets and transport planes, helicopters, warships and submarines, armored vehicles, artillery systems. In 2019, Safran offices are located in many countries around the world, including Morocco, the USA, Canada, Mexico, Chile, Brazil, the United Kingdom, Germany, Poland, the Netherlands, Russia, Malaysia, South Korea, China, India, Singapore, Australia (Safran, The official website).

In Italy, the global high-tech defense and security company is Leonardo, which maintains partnerships with governments, institutions and armed forces of many countries around the world. Leonardo delivers advanced dual-use products and integrated solutions: (1) to enhance global security; (2) to protect people, territories, infrastructure and information networks; (3) to promote sustainable management of the environment, urban spaces and climate. Leonardo representative offices are located in countries such as the United States, Canada, the United Kingdom, Germany, Spain, Poland, Turkey, Romania, Africa, Pakistan, Malaysia, Singapore, Japan, Korea, Thailand, Argentina, Brazil, Chile, the United Arab Emirates, etc. (Leonardo, The official website).

In the UK, BAE Systems is the leading company in the field of national security, critical information protection and infrastructure. BAE Systems employs 85,800 people in more than 40 countries and works closely with local partners to support economic development through the transfer of knowledge, skills and technology. BAE Systems offers a wide range of solutions and services that enable the military and the governments to successfully accomplish their mission. The company provides large-scale engineering, integration systems and service in the aerospace, land, marine and cyber spheres. BAE Systems provides large-scale engineering, integration systems and support services in the aerospace, land, marine and cyber fields. BAE Systems, in particular, provides ammunition, armored vehicles, and bridge equipment to the armed forces worldwide. It is important to emphasize that the company is making a significant industrial and economic contribution to the UK economy, in particular the technology sector (BAE Systems, The official website).

In Sweden, Saab is the leading company serving the world market of governments, authorities and corporations with world leading products, services and solutions from military defense to civil security. Working on every continent, this corporation is constantly developing, adapting and refining new technology to meet the changing needs of customers. By improving technological systems and solutions, Saab's mission is to improve security in the community, its citizens and those whose job it is to support security. The most famous product in the market segment is the Gripen Multipurpose Fighter - a competitive system that can easily integrate new weapons and sensors. The corporation also offers Erieye air traffic monitoring systems, drones, countermeasures, weaponry systems, sensors, training, maintenance and support (Saab Corporate, The official website).

In the area of defense and national security, Saab works in three directions. First, the corporation deals with complex defense orders in which it acts as a direct supplier. These comprehensive solutions, which often include training, maintenance, support, are designed to maintain functionality and cost-effectiveness throughout the product life cycle. Deliveries can continue for several years after development. These systems are configured and tailored to the specific needs of each customer, and therefore often have a large proportion of customer-funded development. In addition, complex defense orders usually entail some form of industrial cooperation.

Second, Saab may be a subcontractor to a partner who has a primary contact with the end customer, for example, when supplying subsystems. Some Saab systems, such as command and control systems, are platform dependent and can be integrated with Saab products or systems or other companies' systems. Another reason to be a subcontractor may be that the cost or other factors make it an effective strategy for establishing presence on a market.

Third, maintenance, support and training can be sold separately, without large defense orders. Consumables and spare parts also belong to this category. These products and solutions are usually sold directly to the customer. Some products and services are delivered on the same day the order is placed and for others it may take more than a year. These orders involve less customer financing than complex systems. Examples include most of Saab's civilian offerings, as well as large-scale items such as ammunition (Saab Corporate, The official website). 
In China, under the supervision of the Ministry of Industry and Information Technology, the State Administration of Science, Technology and Industry for National Defense (SASTIND) is operating. Creation of this agency was intended to strengthen the armed forses with additional personnel and more sophisticated equipment. Priority areas of activity are stockpiling supplies for the army. SASTIND's core responsibilities are related to nuclear weapons, aerospace, aviation, weapons, vessels and electronics industry. In addition, SASTIND aims to promote prosperity of the entire country by stimulating the manufacturing industry, gaining competitive advantages through advanced manufacturing technologies. As an administrative and regulatory body for science, technology and industry for national defense, SASTIND serves the needs of national defense, the armed forses, national economy and military organizations. At the same time, it is responsible for coordinating communications and cooperation on the use of nuclear energy and space activities with countries and international organizations (the State Administration of Science, Technology and Industry for National Defense (SASTIND), The official website).

The Defense Research and Development Organization (DRDO) plays an important role in the research and development at the Ministry of Defense and the Government of India. DRDO is committed to developing advanced defense technologies and the mission of achieving independence in critical defense technologies and systems, providing the armed forces of the country with sophisticated weapons systems and equipment. DRDO was formed in 1958 by the merger of the then functioning Technical Development Establishment (TDE) of the Indian Army and the Directorate of Technical Development and Production (DTDP) at the Defense Science Organization (DSO). At the time DRDO was a small organization of 10 institutions and laboratories. Growing over the years in many areas in terms of subject area diversity, number of laboratories, achievements and status. Presently DRDO is represented by a network of more than 50 laboratories which are engaged in developing defense technologies covering various fields like aeronautics, armaments, electronics, land combat vehicles, engineering systems, missiles, advanced calculations and modelling, materials, Naval Systems, etc. (Defense Research and Development Organization (DRDO), The official website).

Given the above, we can conclude that the defense-industrial complex of the leading European countries is usually represented by 1 or 2 large companies. However, there are exceptions. For example, in Germany, armaments are manufactured by various companies that are subsidiaries of large industrial groups. One of them is Krauss-Maffei Wegmann (KMW), which introduces the world's leading technologies for protection of wheeled and tracked vehicles. Armed forces of more than 50 countries rely on the power and dependability of these unique systems. In the regions of Germany, Brazil, Greece, the United Kingdom, Mexico, Singapore and the United States, more than 4,000 employees develop, supply and service a comprehensive range of products. They range from air transport and armoured wheeled vehicles to reconnaissance, anti-aircraft and artillery systems, to battle tanks, armored personnel carriers and bridge systems. It also includes controls and information systems, as well as remote-control crews with reconnaissance and surveillance equipment. Besides, KMW also has far-reaching system competencies in civil and military modeling (Krauss-Maffei Wegmann, The official website).

Exploring the peculiarities of the defense-industrial complex in Ukraine, it should be noted that after the collapse of the USSR, Ukraine inherited a powerful defense-industrial potential, as well as a third of all the Armed Forces. This is confirmed by the fact that in 1991 there was a military group on the territory of Ukraine, which was notable not only for its quantity but also for its quality. Up to 1996, Ukraine owned 130 intercontinental nuclear missiles, and strategic bombers armed with strategic aviation nuclear warheads were based at the airfields. Tactical nuclear weapons accounted for 3,000 units, and 18\% of the former USSR's defense-industrial complex was located in the country (Baluieva \& Liashenko, 2017).

Presently, the Ministry of Defense of Ukraine, the Ministry for Development of Economy, Trade and Agriculture of Ukraine and the State Concern "Ukroboronprom" act as the responsible authorities in matters of production and transfer (supply, sale) of weapons and military equipment. The Ministry of Defense of Ukraine provides for formation and implementation of the state policy on national security in the military sphere, the field of defense and military construction in time of peace and special period for the military-technical policy 
in the field of defense (Resolution of the Cabinet of Ministers of Ukraine on approval of the Regulation on the Ministry of Defense of Ukraine, 2014).

The Ministry for Development of Economic, Trade and Agriculture of Ukraine is the authorized body for coordinating activities on implementation of the state defense order. In the area of defense and national security of the state the Ministry: (1) prepares and generalizes proposals on formation and implementation of the state policy in the sphere of functioning and development of the defense-industrial complex, development of scientific and technical potential in the field of weapons and military equipment, improvement of the control mechanism of the state in the specified field; (2) identifies, along with other bodies of the security sector and defense sector, the priority directions of the defense-industrial complex development, provides regulatory and legal regulation in the sphere, analyzes the status and tendencies of development of the defense-industrial complex of Ukraine, develops and organizes implementation of development programs for the state defense-industrial complex; (3) ensures coordination of activities undertaken by central and local executive authorities in the field of operation and development of industrial and defense-industrial complex; (4) conducts reviews of the defense-industrial complex in accordance with the procedure established by the law, develops Strategy for development of the defense-industrial complex of Ukraine (Resolution of the Cabinet of Ministers of Ukraine "Issues of the Ministry of Economy, Trade and Agriculture", 2019).

There are two interdepartmental commissions within the National Security and Defense Council of Ukraine: (1) the Interdepartmental Commission on Defense and Industrial Complex; (2) the Interdepartmental Commission on Policy of Military Technical Cooperation and Export Control.

The State Concern Ukroboronprom, established in 2010 in accordance with the Decree of the Cabinet of Ministers of Ukraine "On formation of the State Concern Ukroboronprom" of December 29, 2010, plays an important role in the defense-industrial complex of Ukraine. The main purpose of creation of Ukroboronprom was to increase efficiency of functioning of state-owned enterprises engaged in economic activity in the field of development, manufacture, supply, repair, modernization and utilization of weapons, military and special equipment and ammunition, and to participate in military-technical cooperation with foreign countries. According to the current legislation, as of October 4, 2018, 125 state-owned enterprises were incorporated into the State Concern "Ukroboronprom" (Resolution of the Cabinet of Ministers of Ukraine On Establishment of the State Concern «Ukroboronprom», 2010).

In addition to state-owned enterprises, Ukroboronprom includes 9 joint stock companies. Since 2013, the enterprises of the State Concern have been grouped into 5 main clusters, namely: (1) aircraft construction and aircraft repair; (2) precision weapons and ammunition; (3) armored, automotive, engineering and special vehicles; (4) shipbuilding and marine engineering; (5) radar, radio and air defense systems.

The legal basis for the activities of the State Concern Ukroboronprom (hereinafter referred to as the Concern) is the statute approved by the resolution of the Cabinet of Ministers of Ukraine "Some Issues on the State Concern Ukroboronprom activity" of August 31,2011. The main tasks of the concern are defined as follows:

(1) centralized regulation, control and coordination of the activities of the Concern participants, in particular those who, in due course, obtained the right to export, import of military and dual-use products and services, as well as goods containing state secret information;

(2) to promote efficiency of utilization and development of export, production-scientific and technical potential of the Concern participants;

(3) creation and maintenance of the system of sale of high-tech industrial products, generalization of the results of intellectual activity and performance of works and services;

(4) assistance to the Concern participants in conducting applied research in perspective directions of develop- 
ment of science and technology and introduction of advanced technologies into production;

(5) encouragement of investments in the defense-industrial complex, in particular for creation of competitive models of high-tech industrial products, including military goods;

(6) creation of export-oriented structures in the defense-industrial complex, development of documents necessary for their creation, as well as development and implementation of marketing strategies in the interests of these structures;

(7) capturing international markets for arms, military and special equipment, conducting marketing research, in particular involving representatives of other enterprises and organizations on a contractual basis;

(8) sale of military property in accordance with the agreements concluded with the Ministry of Defense, other central executive authorities, which administer military formations, enterprises and organizations, including non-residents, sale and purchase agreements, swap contracts, deliveries and other civil legal agreements providing for transfer of property rights for military property on a fee or compensation basis (Resolution of the Cabinet of Ministers of «Some issues related to the activity of the State Concern «Ukroboronprom», 2011).

The Concern is administered by the following organs: (1) the Supervisory Board as the supreme governing organ that ensures protection of the state interests, controls and regulates activities of other administrative organs of the Concern; (2) the board of directors is a collegiate administrative organ comprising general director (chairman of the board of directors), his deputies, as well as representatives of members of the Concern; (3) general director (Ukroboronprom, The official website).

It is necessary to emphasize that today the defense-industrial complex of Ukraine is undergoing reform. The strategy of development of the defense-industrial complex of Ukraine is a long-term document of defense planning, which should be based on analysis of the experience of functioning of the sphere over a long period, since the experience of the Ukrainian defense industry until 2014 is a legacy of the USSR (Otsabryk, 2017).

In 2018, the Strategy for development of the defense-industrial complex of Ukraine for the period up to 2028 was approved by Ordinance of the Cabinet of Ministers of Ukraine of June 20, 2018 (hereinafter the Strategy). The necessity to develop the Strategy is demanded by the urgent need to review by the state institutions of Ukraine of the role of the defense-industrial complex in the context of neutralizing internal and external threats to national security, as well as intensifying the economic growth of the state. The Strategy is the basis for developing new and revising existing regulations (including state dedicated programs) in the field of development and operation of the defense-industrial complex. The Strategy defines the long-term priorities of the state military-industrial policy, as well as the directions of realization of the state dedicated programs of reforming and development of the defense-industrial complex in the medium-term perspective (Ordinance of the Cabinet of Ministers of Ukraine On Approving the Strategy for development of the defense-industrial complex of Ukraine for the period up to 2028, 2018).

The main areas of the Strategy are as follows:

(1) optimization of the public administration system by ensuring the integrity of the enterprise management policy and the state policy for development of the defense-industrial complex;

(2) designation of a central executive body that ensures formation and implementation of the state militaryindustrial policy;

(3) optimization of the enterprise asset management, targeting specific goals and priorities for each production segment within the scope of managing state-owned objects in the defense-industrial complex, upgrading production facilities, increasing production rates and volumes; 
(4) determining the priorities for financing the activities of economic entities, taking into account the objectives of the state dedicated programs of reform and development of the defense-industrial complex and development of weapons and military equipment;

(5) implementation of principles of self-sufficiency and ensuring access to defense projects of a wide range of Ukrainian entities of all forms of ownership;

(6) promoting entrepreneurship and continued sustainable functioning of the private sector;

(7) lifting the ban on setting up joint ventures and carrying out joint activities, attracting foreign capital in the development of production capacities of Ukrainian enterprises, improving the system of public-private partnership;

(8) practical implementation of the model of vertically integrated structures by clusters;

(9) corporatization and introduction of corporate governance model;

(10) creation of independent supervisory boards at the enterprises of the defense-industrial complex in accordance with the principles of the Organization for Economic Cooperation and Development;

(11) introduction of partially competitive procedures during selection of defense contractors by state customers;

(12) liberalization of procedures for obtaining powers by economic entities to perform export-import operations in the defense sphere;

(13) establishment of a structure for implementation of innovative defense projects and development of critical technologies in accordance with the practice of the U.S. Defense Advanced Research Projects Agency;

(14) changes in approaches to organization of management processes at the enterprise level, development of human resources, effective personnel policy and application of the principles of assessment of qualification, professional competence, practical achievements and work experience in the defense and security sector;

(15) training of personnel to meet the needs of the defense industry in specialists of the respective qualifications (Ordinance of the Cabinet of Ministers of Ukraine On Approving the Strategy for development of the defenseindustrial complex of Ukraine for the period up to 2028, 2018).

The reform strategy of Ukroboronprom is aimed at integrating the Ukrainian defense-industrial complex into the world high-tech market. The reform aims at close international cooperation within the framework of innovative tendencies and provides for simultaneous work in the legal, technological and industrial fields. An important component of the effective reform is to improve the legal framework and to bring legislation to the world standards. This is confirmed by the fact that 34 bills related to the reform of the Ukrainian defenseindustrial complex have been developed and are currently under consideration. (Ukroboronprom, The official website). See table 1. 
Table 1. Reform Strategy of the State Concern Ukroboronprom

\begin{tabular}{|c|c|}
\hline Key strategic goals & Key strategic initiatives \\
\hline $\begin{array}{l}\text { Reiability } \\
\text { Ensuring defense capability of the country, preventing } \\
\text { threats to the security of the state, strengthening the } \\
\text { international standing of Ukraine }\end{array}$ & $\begin{array}{l}\text { Clustering } \\
\text { (1) cooperation with private companies } \\
\text { (2) optimization of cooperation between manufacturers and researchers } \\
\text { (3) leading technologies and innovative equipment } \\
\text { (4) full cycle production }\end{array}$ \\
\hline $\begin{array}{l}\text { Passionarity } \\
\text { Driver of the reform of the defense-industry complex of } \\
\text { Ukraine, creation of a favorable legislative environment }\end{array}$ & $\begin{array}{l}\text { Audit } \\
\text { (1) an objective view of the Concern by leading international experts } \\
\text { (2) reasonable assurance and protection of investments } \\
\text { (3) clear for investors principles of investing } \\
\text { (4) focus on efficiency of resource utilization } \\
\text { (5) international management standards } \\
\text { (6) unique market offer } \\
\text { (7) roadmap of strategy implementation } \\
\text { (8) reports in line with the international standards }\end{array}$ \\
\hline $\begin{array}{l}\text { Innovation } \\
\text { Development of innovations, involvement of education and } \\
\text { science, partnership with global R\&D centers }\end{array}$ & $\begin{array}{l}\text { Corporatization } \\
\text { (1) transparent management structures } \\
\text { (2) supervisory boards } \\
\text { (3) procedures understood by foreign investors } \\
\text { (4) clear mechanisms for financing and controlling financial flows }\end{array}$ \\
\hline $\begin{array}{l}\text { Effectiveness } \\
\text { Maximum productivity, financial consolidation, expansion } \\
\text { of markets, development of human capital }\end{array}$ & $\begin{array}{l}\text { Main agency for advanced research and development } \\
\text { (1) creation of high-tech solutions } \\
\text { (2) effective tool for developers, investors, and the military } \\
\text { (3) potential for a major breakthrough in the development of the defense } \\
\text { industry }\end{array}$ \\
\hline $\begin{array}{l}\text { Openness and transparency } \\
\text { Combating corruption, transparent ownership of assets, } \\
\text { favorable information policies, openness to international } \\
\text { investors }\end{array}$ & $\begin{array}{l}\text { Protection of technologies } \\
\text { (1) protection of intellectual property in accordance with the international } \\
\text { standards } \\
\text { (2) preserving the intellectual capital of the country } \\
\text { (3) increase of competitiveness } \\
\text { (4) stimulation of further innovation activity }\end{array}$ \\
\hline
\end{tabular}

The table was generated using data from the official website of the State Concern «Ukroboronprom» on the reform strategy.

It is also important to note that in the field of defense industry, Ukraine has signed a number of agreements with foreign countries, including the United Arab Emirates, Turkey, Czech Republic, etc.

In particular, in 2015 an Agreement was signed between the Cabinet of Ministers of Ukraine and the Government of the United Arab Emirates on military and technical cooperation, the main purpose of which was development and organization of military-technical cooperation in the field of technology and defense industry, including preparation, development, recognition of quality and creation of directions of cooperation between state and private enterprises, institutions, organizations of the countries. The main areas of the Agreement were: (1) the defense industry; (2) armaments and military equipment; (3) cooperation on environmental issues and pollution caused by military activities; (4) providing educational services and military training in accordance with the needs and capabilities of the Parties; (5) development, production, modernization, repair and provision of other services in the military-technical sphere; (6) technology, technical assistance in setting up production of weapons and military equipment; (7) exchange of information and experience on standardization, certification and quality control of defense-related products for joint projects; (8) protection of intellectual property rights for the results and intellectual property related to development and production of weapons, ammunition and military equipment; (9) other areas of military-technical sphere that may be of common interest (Agreement between the Cabinet of Ministers of Ukraine and the Government of the United Arab Emirates on military and technical cooperation, 2015). 
In 2017, the Agreement on Military-Financial Cooperation was signed between the Cabinet of Ministers of Ukraine and the Government of the Republic of Turkey in order to further strengthen military cooperation, long-lasting friendly relations and development of the Armed Forces of Ukraine.

In 2006, the Agreement between the Cabinet of Ministers of Ukraine and the Government of the Czech Republic on cooperation in the field of defense industry, providing cooperation in the field of defense industry in the following areas: (1) research, development, modernization, repair and production in the field of defense industry; (2) sale of defense-related products developed or manufactured under joint projects to third countries by mutual agreement; (3) search for possibilities of implementing joint programs for development, production and modernization of defense-related products and associated technical services in the interests of the Armed Forces of the Parties and, if agreed, of third countries; (4) exchange of scientific and technical information, information on standards used by countries of the Parties in the defense industry, information on quality assurance systems, codified data on products manufactured by countries of the Parties and used by another country of the Parties, and exchange of documents, related to all the above fields; (5) participation in military-industrial fairs, commercial exhibitions and symposia organized on the territories of the Parties; (6) cooperation in other areas of defense industry by mutual agreement of the Parties (Agreement between the Cabinet of Ministers of Ukraine and the Government of the Czech Republic on cooperation in the field of defense industry, 2006).

\section{Discussion}

In the course of the study it was found that in Ukraine the responsible authorities in production and transfer (supply, sale) of weapons and military equipment are the Ministry of Defense of Ukraine, the Ministry of Economic Development, Trade and Agriculture of Ukraine and the State Concern "Ukroboronprom". It is important to note that the current Law of Ukraine "On National security of Ukraine" contains rules on the powers of the central executive body, which ensures formation and implementation of the state military-industrial policy (Law of Ukraine On national security of Ukraine, 2018).

Based on the current legislation, the Ministry of Economic Development, Trade and Agriculture of Ukraine is responsible for the functioning and development of the defense-industrial complex. At the same time, the Ministry of Defense of Ukraine is the main user of weapons and military equipment and the coordinator of military and technical policy.

Thus, the issue of control of individual resource branches in the defense industry by various state bodies remains a problem. Improving the efficiency and coherence of the work of this industry, as well as solving the problem of information branching are possible by creating a separate executive body to ensure formation and implementation of the state policy of Ukraine in the field of defense industry.

\section{Conclusions}

Given the above, it can be concluded that the defense-industrial complex of the leading European countries is usually represented by 1 or 2 large companies. For example, in France, the major companies that have become world leaders in the system of defense-industrial complex, are Thales and Safran. In Italy, Leonardo is a global high-tech defense and security company. In the UK, BAE Systems is the leading company in the field of national security, protection of critical information and infrastructure. Saab is the leading company in Sweden serving the world market of governments, authorities and corporations with world leading products, services and solutions from military defense to civil security. However, there are exceptions. For example, in Germany, armaments are manufactured by subsidiaries of large industrial groups.

In Ukraine, the Ministry of Defense, the Ministry of Economic Development, Trade and Agriculture of Ukraine and the State Concern «Ukroboronprom» act as responsible authorities for production and transfer of weapons and military equipment. 
Presently, Ukraine's defense-industrial complex is undergoing reform. In 2018, the Strategy for development of the defense-industrial complex of Ukraine for the period up to 2028 was developed. Reforming the State Concern "Ukroboronprom" is no exception and involves integration of the defense-industrial complex of Ukraine into the world market. The reform is aimed at international cooperation within the framework of innovative tendencies and envisages simultaneous work in the legal, technological and industrial fields. An important component of the effective reform is improvement of the legal framework and approximation of legislation to the international standards. This is confirmed by the fact that 34 bills related to the reform of the Ukrainian defense-industrial complex have been developed and are under consideration at the moment.

\section{References}

Agreement between the Cabinet of Ministers of Ukraine and the Government of the Czech Republic on cooperation in the field of defense industry (2006). URL: https://zakon.rada.gov.ua/laws/show/203_050

Agreement between the Cabinet of Ministers of Ukraine and the Government of the Republic of Turkey on military-financial cooperation (2017). URL: https://zakon.rada.gov.ua/laws/show/792_006-17

Agreement between the Cabinet of Ministers of Ukraine and the Government of the United Arab Emirates on military and technical cooperation (2015). URL: https://zakon.rada.gov.ua/laws/show/784_001-15

Avanesova, N.E., Kolodyazhna, T.V., \& Semenova, J.I. (2018). Strategic platform for economic developmentof enterprises of the military-industrial complex of Ukraine. Naukovyi visnyk Uzhhorodskoho natsionalnoho universytetu, 20(1), 6-9. URL: http://www. visnyk-econom.uzhnu.uz.ua/archive/20_1_2018ua/3.pdf

BAE Systems. The official website. URL: https://www.baesystems.com

Balanovska, T.; Havrysh, O.; Gogulya, O. (2019). Developing enterprise competitive advantage as a component of anti-crisis management, Entrepreneurship and Sustainability Issues 7(1): 303-323. http://doi.org/10.9770/jesi.2019.7.1(23)

Baluieva, O., \& Liashenko, V. (2017). The state and preconditions for the revival of the defense industrialcomplex of Ukraine. Investytsiyi: praktyka ta dosvid, 15, 7481. URL: http://www.investplan.com.ua/?op=1\&z=5635\&i=13

Byrne, E.F. (2017). Military Industrial Complex (MIC). Encyclopedia of Business and Professional Ethics, 1-5. https://doi. org/10.1007/978-3-319-23514-1_209-1

Defense advanced research projects agency (DARPA). The official website. URL: https://www.darpa.mil/

Defence Research and Development Organisation (DRDO). The official website. URL: https://www.drdo.gov.in

Direction générale de l'armement (DGA). The official website. URL: https://www.defense.gouv.fr/dga/la-dga2/missions/presentationde-la-direction-generale-de-l-armement.

Durmanov, A., Bartosova, V., Drobyazko, S., Melnyk, O., Fillipov, V. (2019). Mechanism to ensure sustainable development of enterprises in the information space. Entrepreneurship and Sustainability Issues, 7(2), 1377-1386. http://doi.org/10.9770/jesi.2019.7.2(40)

Khmara, O. (2016). International production networks in defense industry. Visnyk Kyivskoho natsionalnoho universytetu imeni Tarasa Shevchenka, 1(44/45), 70-76. URL: http://journals.iir.kiev.ua/index.php/knu/article/view/3247

Korauš, A., Gombár, M., Kelemen, P.. Backa, S. (2019). Using quantitative methods to identify insecurity due to unusual business operations, Entrepreneurship and Sustainability Issues 6(3): 1101-1012. http://doi.org/10.9770/jesi.2019.6.3(3)

Krauss-Maffei Wegmann, The official website. URL: https://www.kmweg.de

Kulish A., Andriichenko N., Reznik O. (2018) A step forward in the minimization of political corruption in financial support of political parties: The experience of Ukraine and Lithuania. Baltic Journal of Law and Politics. DOI: 10.2478/bjlp-2018-0005.

Law of Ukraine On national security of Ukraine (2018). URL: https://zakon.rada.gov.ua/laws/show/2469-19/ed20180621\#n21

Leonardo. The official website. URL: https://www.leonardocompany.com

Nzeribe, S., \& Imam, M. (2018). The military industrial complex: a catalyst for conflicts and wars (USA). Journal of Social Development, 7(1), 73-81. https://doi.org/10.12816/0046772 
Ordinance of the Cabinet of Ministers of Ukraine On Approving the Strategy for development of the defense-industrial complex of Ukraine for the period up to 2028 (2018). URL: https://zakon.rada.gov.ua/laws/show/442-2018-\%D1\%80

Otsabryk, I.I. (2017). The defense industrial complex of Ukraine in an economy postindustrial society conditions: analysis and perspectives. Visnyk natsionalnoho universytetu "Lvivska Politekhnika”. Seriia: Menedzhment ta pidpryiemnytstvo v Ukraini: etapy stanovlennia i problemy rozvytku, 875, 329-334. http://dx.doi.org/10.30525/978-9934-571-28-2_21

Potomkina, M. (2018). Theoretical and legal foundations of economic legal relations in the defense industry of Ukraine. Part One. Pidpryiemnytstvo, hospodarstvo i pravo, 2, 58-62. URL: http://pgp-journal.kiev.ua/archive/2018/2/12.pdf

Sitdikova, L.B., Starodumova, S.J. (2019). Corporate agreement as a means of providing security in the course of entrepreneurship development, Entrepreneurship and Sustainability Issues 7(1): 324-335. http://doi.org/10.9770/jesi.2019.7.1(24)

Qureshi, F.A. (2018). The Military Industrial Complex and its typology in the context of its political framework. International Journal of Political Science and Development, 6(5), 123-130. https://doi.org/10.14662/IJPSD2018.035

Resolution of the Cabinet of Ministers of Ukraine «Issues of the Ministry of economy, trade and agriculture» (2019). URL: https:// zakon.rada.gov.ua/laws/show/838-2019-\%D0\%BF

Resolution of the Cabinet of Ministers of Ukraine On Establishment of the State Concern «Ukroboronprom» (2010). As amended up to Act of October 24, 2018. URL: https://zakon.rada.gov.ua/laws/show/1221-2010-\%D0\%BF

Resolution of the Cabinet of Ministers of Ukraine On approval of the Regulation on the Ministry of defense of Ukraine (2014). As amended up to Act of January 15, 2019. URL: https://zakon.rada.gov.ua/laws/show/671-2014-\%D0\%BF

Resolution of the Cabinet of Ministers of Ukraine «Some issues related to the activity of the State concern «Ukroboronprom» (2011). As amended up to Act of October 04, 2018. URL: https://zakon.rada.gov.ua/laws/show/849-2018-\%D0\%BF\#n6

Saab Corporate, The official website. URL: https://saab.com

Safran. The official website. URL: https://www.safran-group.com

Smart, B. (2016). Military-industrial complexities, university research and neoliberal economy. Journal of Sociology, 3(52), 455-481. https://doi.org/10.1177/1440783316654258

Solopenko, T. (2016). Expenditures on defense: current state and perspectives (on the example of the USA, Russia and Ukraine). Stratehiia ekonomichnoho rozvytku Ukrainy, 38, 87-97. URL: http://ir.kneu.edu.ua/handle/2010/19468

State Administration of Science, Technology and Industry for National Defense (SASTIND). The official website. URL: http://www. sastind.gov.cn

Thales. The official website. URL: https://www.thalesgroup.com

Ukroboronprom. The official website. URL: https://ukroboronprom.com.ua

Usachenko, O. (2019). Experience of state regulation of the reform of the US and EU defense industrial complex. Derzhavne upravlinnia: udoskonalennia ta rozvytok, 7. https://doi.org/10.32702/2307-2156-2019.7.24 
JOURNAL OF SECURITY AND SUSTAINABILITY ISSUES

ISSN 2029-7017 print/ISSN 2029-7025 online

Short biographical note about the contributors at the end of the article:

Dmytro ZHURAVLOV, Doctor of Juridical Sciences, Professor, Institute of Law and Postgraduate Education of the Ministry of Justice of Ukraine

ORCID ID: orcid.org/0000-0003-2886-695X

Viktoriia ANISHCHUK, Candidate of Juridical Sciences, Lutsk National Technical University

ORCID ID: orcid.org/0000-0002-1485-4588

Denys CHYZHOV, Candidate of Juridical Sciences, Military Institute of Taras Shevchenko National University of Kyiv ORCID ID: orcid.org/0000-0002-4843-0670

Volodymyir PASHYNSKYI, Candidate of Juridical Sciences, Associate Professor, National Defence University of Ukraine named after Ivan Cherniakhovskyi

ORCID ID: orcid.org/0000-0001-6511-2482

Mykola ZAITSEV, Candidate of Juridical Sciences, Central Research Institute of the Armed Forces of Ukraine

ORCID ID: orcid.org/0000-0003-0322-5910

This work is licensed under the Creative Commons Attribution International License (CC BY). http://creativecommons.org/licenses/by/4.0/ 